\title{
Desain Multi-purpose Support Ship sebagai Sarana Pengamanan, Pemetaan, dan Pusat Komando untuk Meningkatkan Keamanan Perairan Indonesia
}

\author{
Dewangga Aradea Widjatmiko dan Hesty Anita Kurniawati \\ Departemen Teknik Perkapalan, Fakultas Teknologi Kelautan, Institut Teknologi Sepuluh Nopember (ITS) \\ Jl. Arief Rahman Hakim, Surabaya 60111 Indonesia \\ e-mail: tita@na.its.ac.id
}

\begin{abstract}
Abstrak-Akibat maraknya pelanggaran-pelanggaran seperti illegal fishing, perompakan, penyelundupan, dan pelanggaran wilayah perbatasan laut Sulawesi, Indonesia. maka dibutuhkan kapal yang memiliki beragam kemampuan yaitu sebagai kapal kombatan (anti kapal permukaan, anti kapal selam, dan anti serangan udara), kapal markas (command ship), kapal hidro-oseonagrafi (kapal survey dan riset), kapal bantu angkut personel dan kendaraan tempur (support ships), dan kapal pengawas lingkungan (environmental protection). Jenis kapal yang dibuat adalah Multi-purpose Support Ship (MSS), dikarenakan kegunaan yang dapat diubah sesuai dengan kebutuhannya. Sehingga diharapkan dapat meningkatkan keamanan laut Indonesia. Dari proses desain ini didapat ukuran Multi-purpose Support Ship yaitu; Lpp = 110.0 m, B =14 m, H= 6.5 m, T= 4,5 m..
\end{abstract}

Kata Kunci- Indonesia, keamanan, Laut Sulawesi, Multipurpose Support Ship (MSS).

\section{PENDAHULUAN}

I NDONESIA merupakan negara maritim yang memiliki wilayah perairan yang luas. Karena memiliki daerah perairan yang luas, maka rentan terjadi pelanggaran seperti illegal fishing, perompakan, penyelundupan, dan pelanggaran wilayah perbatasan laut Indonesia.

Berdasarkan dengan data yang dimiliki oleh TNI-AL dan BAKAMLA, negara Indonesia memiliki armada untuk menjaga keamaan laut yang tidak memadai. Hal ini dikarenakan adanya kapal-kapal yang digunakan mengalami kerusakan, sudah mencapai umur yang tidak layak pakai, serta kekurangan jenis kapal yang dibutuhkan. Contohnya untuk kapal hidro-oseanografi, Indonesia hanya memiliki 2 kapal, sedangkan untuk memetakan seluruh peta bawah laut 2 kapal ini tidak cukup untuk mengjangkau keseluruhan [1]. Kemudian untuk kapal yang berpatroli disekitar perbatasan dengan negara lain, Indonesia memiliki armada dan teknologi yang tidak mencukupi untuk menjaga perbatasan. Serta untuk kapal komando Indonesia tidak memilikinya, sehingga harus menggunakan kapal berjenis landing dock platform sebagai pusat komando.

Dikarenakan kegunaan yang dapat dirubah sesuai dengan kebutuhannya. maka dibuat kapal multi-purpose support ship yang memiliki beragam kemampuan yaitu sebagai kapal kombatan (anti kapal permukaan, anti kapal selam, dan anti serangan udara), kapal ranjau (penyebar-pemburupenyapu ranjau), kapal markas (command ship), kapal hidrooseonagrafi (kapal survey dan riset), kapal pengintai (surveillance), kapal pengumpul data intelijen elektronika (signal inteligent), kapal bantu angkut personel dan kendaraan tempur (support ships), dan kapal pengawas lingkungan (environmental protection) [2] .

\section{STUDI LITERATUR}

\section{A. Laut Sulawesi}

Laut Sulawesi di barat Samudra Pasifik dibatasi oleh Kepulauan Sulu, Laut Sulu, dan Pulau Mindanao, Filipina, di utara, di timur oleh rantai Kepulauan Sangihe, di selatan oleh Sulawesi, dan di barat oleh Kalimantan, Indonesia. Laut ini berbentuk basin besar, dan kedalamnya mencapai $6.200 \mathrm{~m}$. Memanjang $420 \mathrm{mil}(675 \mathrm{~km})$ utara-selatan dengan 520 mil $(837 \mathrm{~km})$ timur-barat dan wilayah permukaan totalnya $110.000 \mathrm{mil}^{2}\left(280.000 \mathrm{~km}^{2}\right)$. Laut ini merupakan salah satu tempat rawan terjadinya pembajakan, illegal fishing, dan penyulundupan karena merupakan daerah pelayaran internasional.

\section{B. Kapal Kombatan}

Kapal kombatan adalah kapal perang bersenjata yang lazim dimiliki oleh angkatan laut yang digunakan untuk pertempuran langsung di lautan. Umumnya dipersenjatai dengan meriam, meriam anti serangan udara, peluru kendali baik anti serangan udara, anti kapal selam, maupun terhadap sasaran di darat, torpedo, ranjau, bahkan rudal jelajah.

\section{Hydro-oceanographic Research Vessel}

Kapal yang didesain khusus untuk membawa peralatanperalatan untuk melakukan penelitian seperti hidrografi dan survey grafik bahari. Informasi yang hasil penelitian digunakan untuk kepentingan navigasi pelayaran militer dan sipil (Adler, 2013) [3].

\section{Kapal Komando}

Kapal komando berfungsi sebagai kapal pemimpin yang menyediakan sarana komunikasi, ruang kantor, dan akomodasi untuk komandan armada dan stafnya, dan berfungsi untuk mengkoordinasikan kegiatan armada, karena sifat dari kapal sebagai kapal komando, maka disediakan ruangan khusus untuk komandan penyerangan

\section{E. Sistem modular}

Sistem modular dapat diartikan sebagai, penggunaan beberapa jenis sistem dalam suatu bagian kapal secara bergantian sehingga dapat merubah fungsi utama kapal tersebut.

\section{METEDOLOGI PENELITIAN}

\section{A. Diagram Alir}

Tahapan dari metodologi penelitian yang digunakan digambarkan pada Gambar 1. Diagram alir 


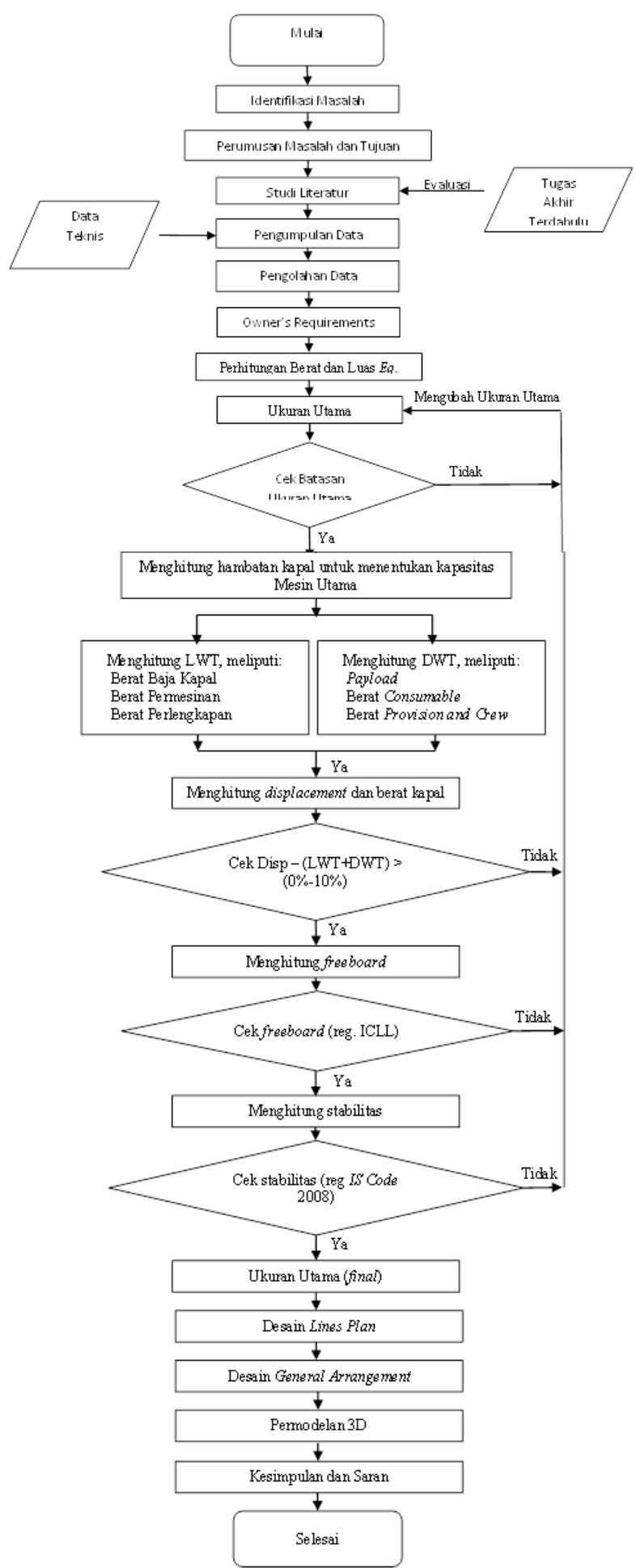

Gambar 1. Diagram alir

\section{ANALISIS TEKNIS DAN DESAIN MSS}

\section{A. Design Statement}

Data owners requirements dari Program Tol Sungai ini adalah:

1.Payload berupa berat persenjataan dan sensor yang dibutuhkan seberat 333,59 ton dan luasan untuk peletakan persenjataan dan sensor adalah 436,729 $\mathrm{m}^{2}$.

2. Rute pelayaran adalah perairan Laut Sulawesi, Indonesia.

3. Kapal didesain dengan kecapatan 30 knot $(55,56 \mathrm{~km} / \mathrm{h})$ saat melakukan pengejaran dan $15 \mathrm{knot}(27,78 \mathrm{~km} / \mathrm{h})$ saat melakukan pelayaran.

\section{B. Penentuan Payload}

Penentuan payload berdasarkan data berat dan luasan persenjataan

Tabel 1.

Penentuan Payload

\begin{tabular}{|c|c|c|}
\hline Payload & $\begin{array}{c}\text { Luas } \\
\mathrm{m}^{2}\end{array}$ & $\begin{array}{c}\text { Berat } \\
\text { ton }\end{array}$ \\
\hline \multicolumn{3}{|c|}{ Helicopter } \\
\hline Eurocopter ASN65N3 & 202.5 & 8.6 \\
\hline \multicolumn{3}{|c|}{ Sonar } \\
\hline Sonar Cabinet Unit & 1.26 & 0.32 \\
\hline Hoisting Unit & 5.64 & 2.3 \\
\hline Hydraulics Unit & 1.68 & 0.55 \\
\hline Indicator Unit & 1.1 & 0.0024 \\
\hline Power Supply Unit & 0 & 0.225 \\
\hline HUGIN & 5.5 & 10 \\
\hline Side Scan Sonar & 0.2 & 0.007 \\
\hline \multicolumn{3}{|c|}{ Weapon } \\
\hline \multicolumn{3}{|c|}{ Close-In Weapon System } \\
\hline Gun Mount Above Deck & 30.25 & 6.8 \\
\hline Transmitter Cabinet & 13.5 & 1.12 \\
\hline Receiver \& FCU Cabinet & 0.938 & 0.31 \\
\hline $\begin{array}{l}\text { Waveguide drier } \\
\text { Mount Control Electronics }\end{array}$ & $\begin{array}{l}0.436 \\
1.549\end{array}$ & $\begin{array}{c}0.083 \\
1.23\end{array}$ \\
\hline Weapon Control Console & 0.962 & 0.32 \\
\hline System Interface Cabinet & 1.110 & 0.61 \\
\hline Deck Junction Box & 0.275 & 0.064 \\
\hline Circulator Unit & 0.196 & 0.026 \\
\hline \multicolumn{3}{|c|}{ Ship to Ship Weapon System } \\
\hline Gun System & 20 & 14 \\
\hline \multicolumn{3}{|c|}{ Ship to Air Weapon System } \\
\hline Vertical Launch System & 56.32 & 240 \\
\hline Tomahawk Missiles & & 29.6 \\
\hline \multicolumn{3}{|c|}{ Ship to Sub Weapon System } \\
\hline Torpedo Launcher & 13.5 & 8 \\
\hline Torpedo & 6 & 2.76 \\
\hline \multicolumn{3}{|c|}{ Radar } \\
\hline Antenna & & 1.1 \\
\hline Control Cabinet & 0.3375 & 0.215 \\
\hline Hydraulic Unit & 0.325 & 0.5 \\
\hline Transmitter Cabinet & 1.785 & 1.5 \\
\hline Receiver Cabinet & 0.72 & 0.35 \\
\hline Remote Control & 0.156 & 0.015 \\
\hline Waveguide drier & 0.49 & 0.083 \\
\hline \multicolumn{3}{|c|}{ RHIB } \\
\hline ASIS NAVY 9.5M & 70 & 5.8 \\
\hline & 436.729 & 336.49 \\
\hline
\end{tabular}

\section{Layout Awal}

Dalam mendesain sebuah kapal, diperlukan Gambar 2. Layout awal MSS dan Tabel 2.

Luas ruangan minimum menunjukkan gambaran umum mengenai desain yang akan dibentuk. 
Tabel 2.

Luas ruangan minimum

\begin{tabular}{ccc}
\multicolumn{3}{c}{ Luas ruangan minimum } \\
\hline \hline & Keterangan & Luas $\left(\mathrm{m}^{2}\right)$ \\
A & Helideck \& Hangar & 202.500 \\
& & \\
B & Weaponry & 145.036 \\
C & Sensor & 53.029 \\
D & RHIB & 70 \\
\hline \hline
\end{tabular}
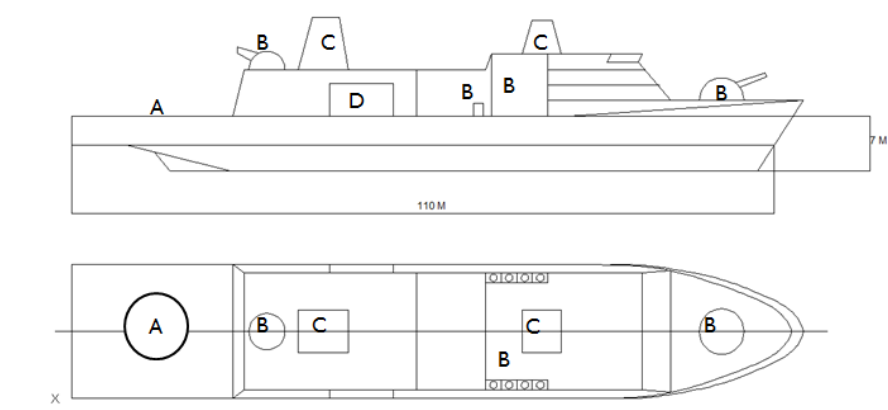

Gambar 2. Layout awal MSS

\section{Rute Pelayaran}

Gambar 3. Rute Pelayaran MSS tersebut merupakan daerah perbatasan antara Indonesia dengan Filipina. Jarak yang untuk rute pelayaran $2,237 \mathrm{~km}$.

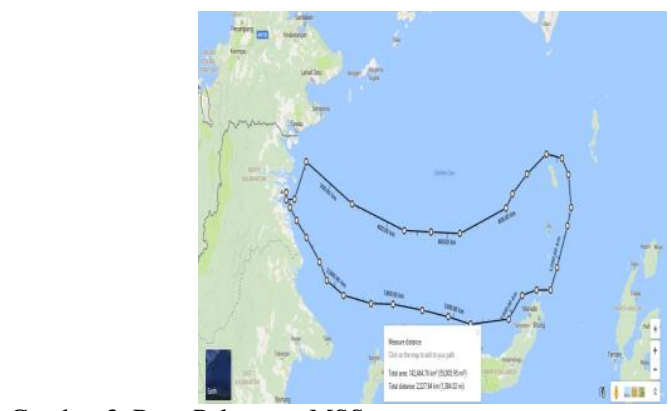

Gambar 3. Rute Pelayaran MSS

\section{E. Penentuan Ukuran Utama}

Metode penentuan ukuran utama yang digunakan dalam penelitian ini adalah dengan menggunakan metode Iterative Design Approach. Metode desain kapal yang berdasarkan pada proses siklus dari prototyping, testing, dan analyzing (trial and error) (Evans, 1959) [4]. Perubahan dan perbaikan akan dilakukan berdasarkan hasil pengujian iterasi terbaru sebuah desain. Proses ini bertujuan untuk meningkatkan kualitas dan fungsionalitas dari sebuah desain yang sudah ada.

\section{F. Rekapitulasi Hasil Analisis Perhitungan Teknis}

Proses perhitungan awal dilakukan berdasarkan dari ukuran utama awal berdasarkan ukuran layout awal menggunakan metode Iterative Design Approach. Berikut merupakan Tabel 3.

Rekapitulasi hasil perhitungan teknis: Tabel 3.

Rekapitulasi hasil perhitungan teknis

\begin{tabular}{ccc}
\hline \hline Kriteria & Value & Satuan \\
Length $(\mathrm{L})$ & 110.000 & $\mathrm{M}$ \\
Length $\left(\mathrm{L}_{\mathrm{WL}}\right)$ & 114.400 & $\mathrm{M}$ \\
Breadth $(\mathrm{B})$ & 14.000 & $\mathrm{M}$ \\
Draft $(\mathrm{T})$ & 4.500 & $\mathrm{M}$ \\
Height $(\mathrm{H})$ & 6.500 & $\mathrm{M}$ \\
Vol. Disp $(\overline{\mathrm{v}})$ & 3784.579 & $\mathrm{~m}^{3}$ \\
Displ. Ton $(\underline{\Lambda})$ & 3879.193 & Ton \\
L/B & 7.857 & \\
\hline \hline
\end{tabular}

\begin{tabular}{ccc}
\hline \hline $\mathrm{B} / \mathrm{T}$ & 3.111 & \\
$\mathrm{~L} / \mathrm{T}$ & 24.444 & \\
$\mathrm{C}_{\mathrm{B}}$ & 0.525 & \\
$\mathrm{C}_{\mathrm{M}}$ & 0.790 & \\
$\mathrm{C}_{\mathrm{P}}$ & 0.665 & \\
$\mathrm{C}_{\mathrm{WP}}$ & 0.800 & \\
$\mathrm{R}_{\mathrm{T}}$ & 545.587 & $\mathrm{kN}$ \\
$\mathrm{P}_{\text {Req. Pursuit }}$ & 26140.976 & $\mathrm{x} 1 \mathrm{~kW}$ \\
$\mathrm{P}_{\text {Req Voyage. }}$ & 5665.760 & $\mathrm{x} 2 \mathrm{~kW}$ \\
$\mathrm{P}_{\text {GenReq. }}$ & 708.220 & $\mathrm{x} 4 \mathrm{~kW}$ \\
$\mathrm{DWT}$ & 1731.878 & ton \\
LWT & 2016.958 & ton \\
LWT + DWT & 3748.836 & ton \\
LCB & 55.666 & $\mathrm{~m}(\mathrm{FP})$ \\
LCG & 58.318 & $\mathrm{~m}(\mathrm{FP})$ \\
Freeboard & 2 & $\mathrm{M}$ \\
\hline \hline
\end{tabular}

Setelah dilakukan proses perhitungan, maka didapat ukuran utama MSS yang telah memenuhi persyaratan teknis dan regulasi, maka didapatkan ukuran sebesar: L (panjang) $=110 \mathrm{~m}, \mathrm{~B}($ lebar $)=14 \mathrm{~m}, \mathrm{H}($ tinggi $)=6.5 \mathrm{~m}, \operatorname{dan} \mathrm{T}($ sarat $)$ $=4.5 \mathrm{~m}$.

\section{G. Desain Rencana Garis}

Desain Rencana Garis yang dibuat harus memperhatikan dengan kriteria teknis dari perhitungan teknis yang telah dilakukan sebelumnya. Gambar 6. Rencana Garis MSS berikut merupakan hasil desain Rencana Garis dengan bantuan perangkat lunak:

\section{H. Desain Rencana Umum}

Desain Rencana Umum yang dibuat harus memperhatikan perencanaan dan pembagian ruang untuk kebutuhan kapal. Rencana Umum dibuat berdasarkan Rencana Garis yang telah dibuat sebelumnya. Dengan Rencana Garis, secara garis besar bentuk badan kapal akan terlihat serta menentukan pembagian ruangan sesuai dengan fungsinya. Gambar 5. Rencana Umum MSS berikut merupakan hasil desain Rencana Umum dengan bantuan perangkat lunak:

\section{Desain Safety Plan}

Desain Safety plan yang dibuat harus memperhatikan langkah-langkah yang perlu dilakukan keadaan saat terjadi kecelakaan. Gambar 7. Safety Plan MSS dibuat berdasarkan Rencana Umum yang telah dibuat sebelumnya

Pemodelan 3DError! Reference source not found. merupakan hasil pemodelan menggunakan bantuan perangkat lunak dibuat berdasarkan Lines Plan, General Arrangement, persenjataan, sensor, dan peralatan yang digunakan pada MSS.

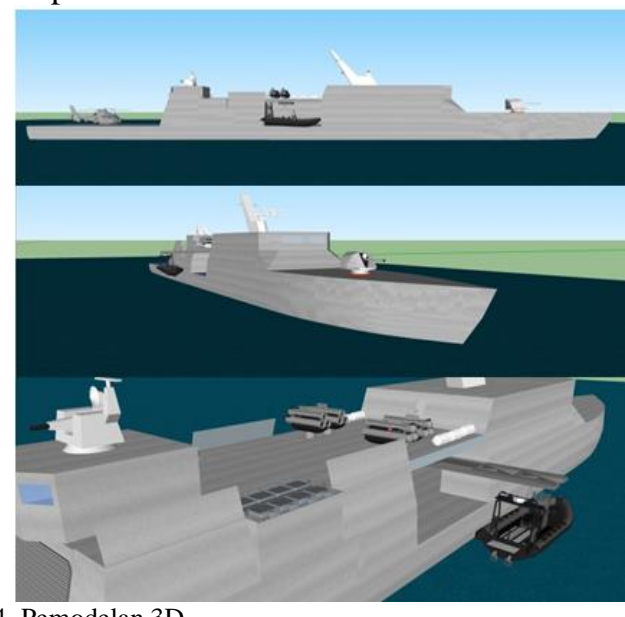

Gambar 4. Pemodelan 3D 


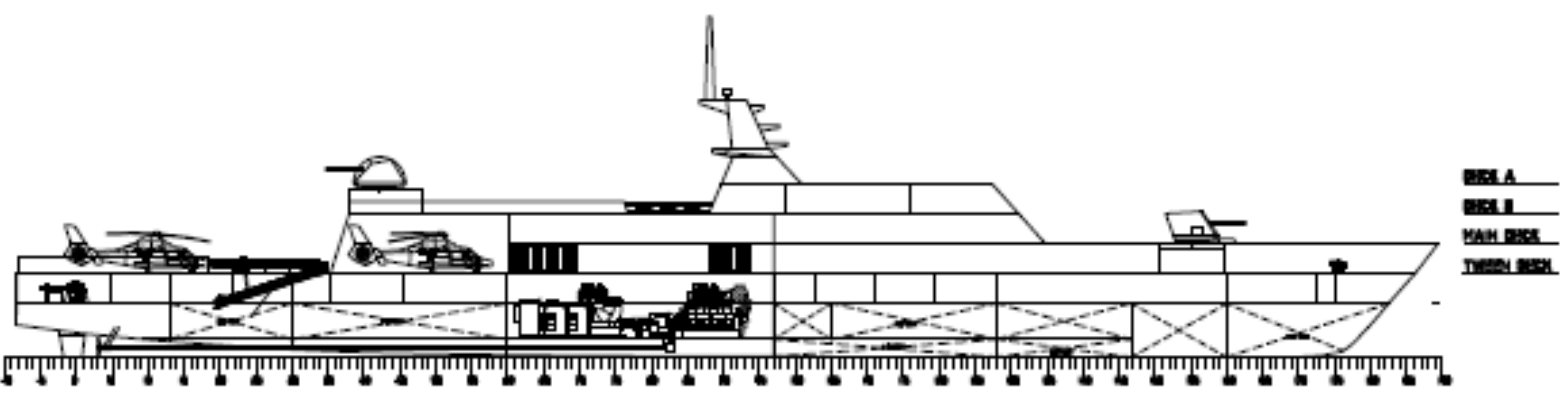

!n!

Dnte

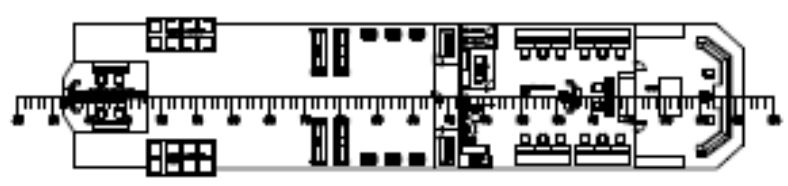

Dente
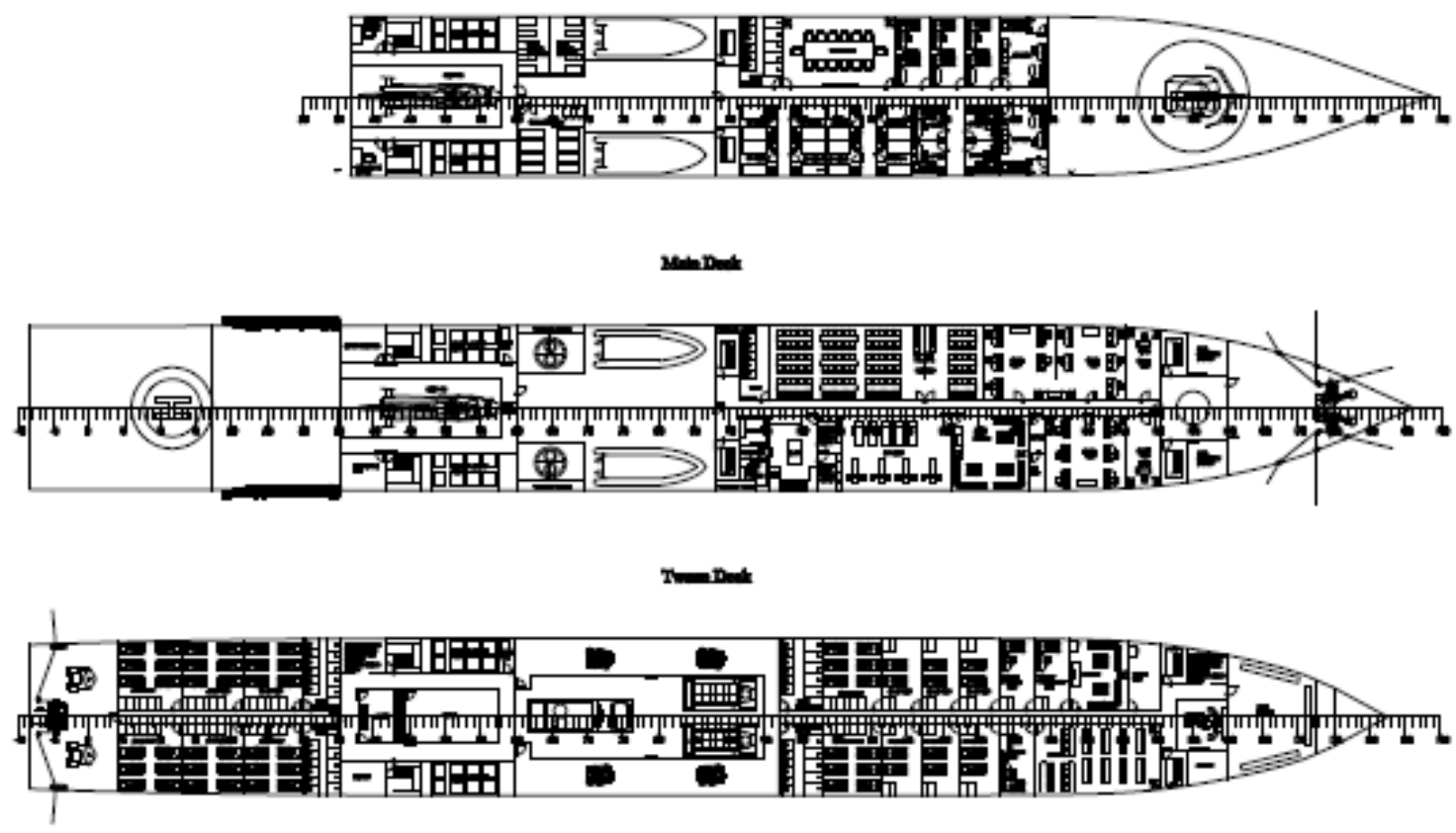

inding
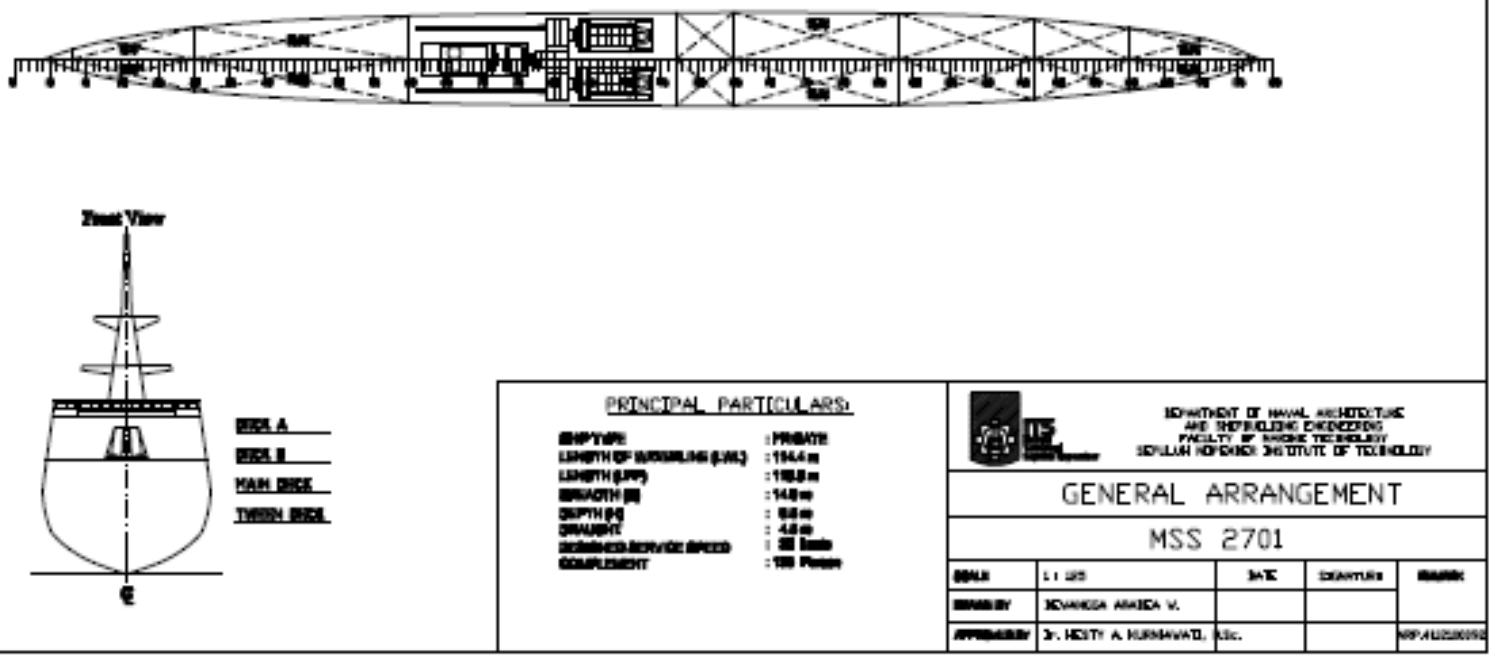

Gambar 5. Rencana Umum MSS 

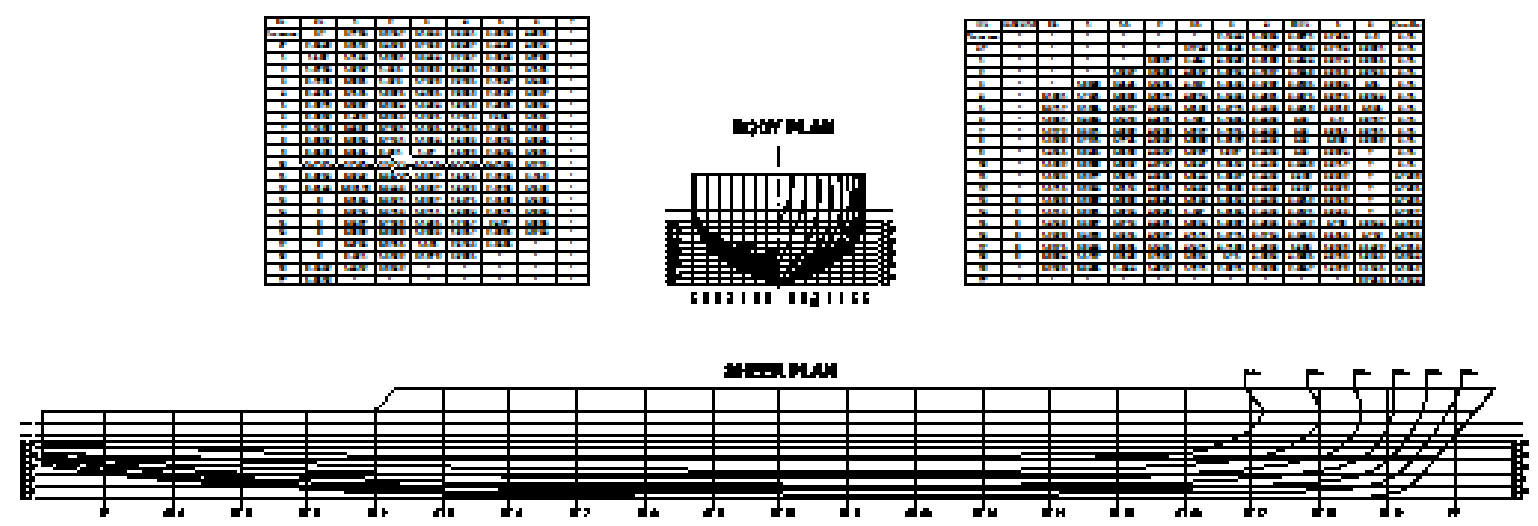

\section{Mremerm}
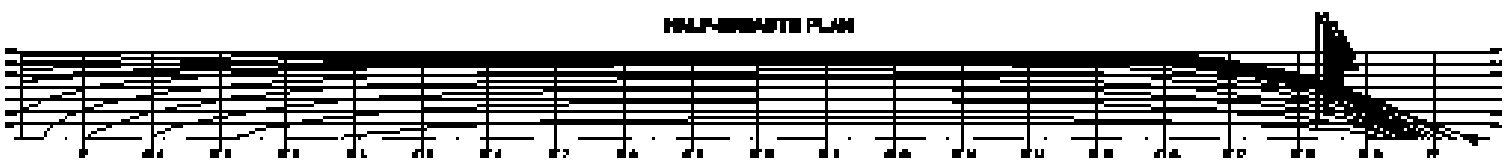

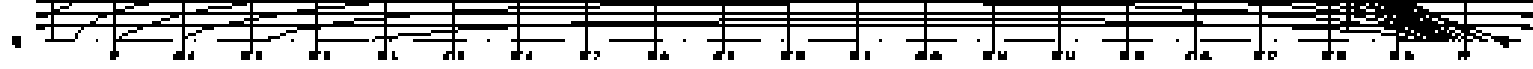

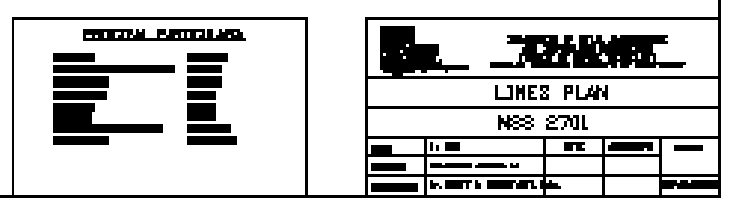

Gambar 6. Rencana Garis MSS
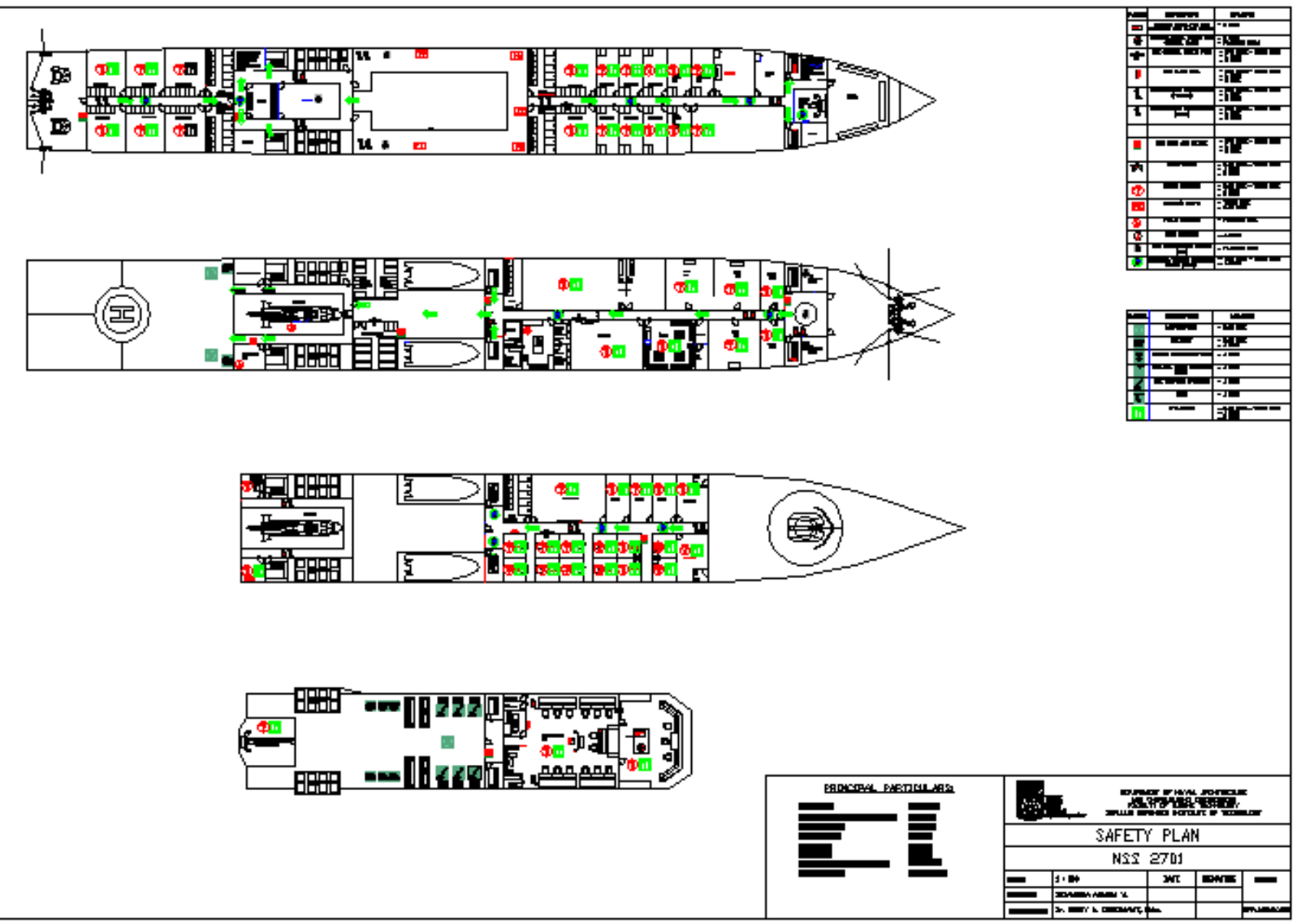


\section{KESIMPULAN DAN SARAN}

Berdasarkan analisis teknis dan ekonomis yang telah dilakukan, maka dapat ditarik kesimpulan sebagai berikut:

1. Rute pelayaran di perairan Laut Sulawesi dengan jarak pelayaran $2250 \mathrm{~km}$

2. Dari hasil analisis teknis berupa prosses didapatkan ukuran utama MSS sebagai berikut:
a. $\mathrm{L}_{W L}: 114.00 \mathrm{~m}$
b. LPP : $110.00 \mathrm{~m}$
c. $\mathrm{B}: 14.00 \mathrm{~m}$
d. $\mathrm{H}: 6.5 \mathrm{~m}$
e. $\mathrm{T}: 4.5 \mathrm{~m}$

3. Gambar desain Rencana Garis, Rencana Umum, Safety Plan, dan Pemodelan 3D terlampir.

Saran yang dapat diberikan pada Jurnal ini antara lain:

a. Karena permasalah dalam Jurnal ini merupakan solusi terhadap peningkatan keamanan dari Pemerintah Pusat, maka diperlukan adanya peninjauan lebih lanjut terhadap aspek kebijakannya.

b. Perlu adanya peninjauan lebih lanjut terhadap aspek konstruksi dan kekuatan kapal mengingat pada Jurnal ini masih banyak digunakan perhitungan secara pendekatan.

\section{DAFTAR PUSTAKA}

[1] (n.d.).http://nasional.sindonews.com/read/1157616/14/tni-al-butuh12-kapal-untuk-pantau-dasar-laut-1479889461

[2] (n.d.).http://www.tnial.mil.id/News/OperasiLatihan/tabid/80/articleT ype/ArticleView/articleId/1526/8--PRAJURIT-POM-TNI-DILEBANON-NAIK-PANGKAT.aspx

[3] Adler, Antony. (2013). The Ship as Laboratory: Making Space for Field Science at Sea. Journal of the History of Biology.

[4] Evans, J.H. (1959). Basic Design Concepts. Massaschussetts: Cornrll Maritime Press Inc. 